\title{
Dissecting Perceptions of New Graduates on Work Orientation and Self-Confidence in Employability Skills Training Program
}

\author{
Mohd Hazwan Mohd Puad ${ }^{1, *}$, Hazeem Mohamad Desa ${ }^{2}$ \\ ${ }^{1}$ Faculty of Educational Studies, Universiti Putra Malaysia, Malaysia \\ ${ }^{2}$ Sekolah Menengah Kebangsaan Taman Bunga Raya (I), Malaysia
}

Received October 27, 2019; Revised December 2, 2019; Accepted December 24, 2019

Copyright $\odot 2020$ by authors, all rights reserved. Authors agree that this article remains permanently open access under the terms of the Creative Commons Attribution License 4.0 International License

\begin{abstract}
Work orientation and self-confidence are among key factors that lead to work performance of individual. Both factors are considered as among the predictors to influence productivity of new and experienced workers. This study is aimed to identify the level of work orientation and self-confidence among new graduates who participated in the work retention and skills enhancement program, Skim Latihan 1 Malaysia (SL1M). Also the study is intended to assess trainees' perceptions on employability skills training program, SL1M. This is a quantitative study using descriptive design. A total of 108 respondents were randomly selected from new graduates who were involved in the SL1M training program. This study is a quantitative research by using questionnaire instrument. Descriptive data were analyzed by using IBM SPSS Statistics software. The findings indicate the level of work orientation and self-confidence was high among respondents. The SL1M trainees are prepared to change their method of work if necessary in order to fulfill work requirement and demand. The trainees also believe that they possess a quality to work in the industry and can be offered to employers.
\end{abstract}

Keywords Work Orientation, Self-Confidence, Skills Enhancement, Job Retention

\section{Introduction}

Malaysia is making its way into a developed country. In line with economic, political, and social progress it wants to achieve the education system in the country, which is also in the progress of transformation. The transformation involves of producing more knowledgeable, talented, and skilled graduates and people for the nation. With the pool of knowledgeable, talented, and skilled citizens, it is hoped that Malaysian workers can be more productive, creative, and resistant to future challenges, thus, propelling the country to be more prosperous and flourish. According to Graduate Detection Report 2017, Malaysia has successfully produced 299,635 new graduates through public and private colleges and universities all over the country (Ministry of Education Malaysia, 2019). This number has increased $13.4 \%$ since five years ago. However, the number of new graduates could be more meaningful if they can secure a job in the market. From the record, 19.8\% of new graduates from all field of studies are unemployed. This issue is often raised when graduates are now seen as failing to meet the demands of the industrial market (Muhammad Hazrul Ismail, 2012).

Report from the Department of Statistics Malaysia (2019), depicts that the unemployment rate in Malaysia is at $3.3 \%$ with 520,000 people. The unemployment rate in Malaysia is seen to be dominated by youths aged 15 to 24 by $10.8 \%$. This number is increasing every year and creates insecurity in the job market among new graduates.

One of the problems of unemployment is because graduates possess qualifications that are not required by the job market and lack skills required in their field (Chang, 2004). According to Nurita, Shaharudin and Ainon (2004), comments from employers show that the new graduates possess relevant skills in the field of study. However, they are lacking soft skills. Employers today are more likely to hire graduates who are balanced in terms of academic knowledge and soft skills such as communication skills, problem solving skills, teamwork skills and critical thinking skills. The employability skills training programs are initiated in Malaysia starting in 2010 with the aim of reducing the unemployment problem that has plagued the country, especially among new graduates. The government has introduced employability skills training programs to enhance skills of graduates and match job demand with qualification of graduates. One of the programs introduced 
in the 10th Malaysia Plan is the Graduate Employability Management Scheme that aimed at helping graduates get jobs (Mohd Hazwan Mohd Puad, 2018). The purpose of the program was to help graduates adapt to the work environment, equip graduates with the skills needed to work and assist in matching graduates with jobs opportunities.

In addition, the government has introduced the Skim Latihan 1 Malaysia (SL1M) in 2011 as part of the initiative to reduce unemployment in the country. The purpose of the program is to increase the marketability of new graduates through soft skills training and job training towards reducing the country's unemployment rate. The program targets unemployed graduates from low-income families in rural areas as well as graduates who are working with jobs that do not match with their qualifications (Economic Planning Unit, 2017). Participants in the program will undergo on-the-job training on soft skills with participating companies to enhance their self-confidence and work orientation in the real working environment. Through this program, graduates will be trained in not limited to five key employability skills including communication skills, creative thinking, workplace adaptation, professionalism and work ethic (Mastura et al., 2013). Today's work is seen as requiring not only high technical skills but also the need for mastery of related employability skills. Mastura et al (2013) conducted a study to look at unemployed graduates' perceptions of their communication skills in training program. The findings show that despite the success of the training program, the level of communication skills is at moderate level. They are not ready to adapt to the changing workplace. They show that their personal skills are among factors to contribute to the lack of skills of new graduates.

Research found that work orientation is strongly associated with employability skills (Van Dam, 2004). In addition, employees are seen as likely to improve their employability skills if given the opportunity to be in a new situation. Workers who have been in an organization for a long time are seen as having a high commitment but low in terms of improving their skills. Employees with a positive work orientation are more likely to see opportunities within an organization whether at work or beyond, and thus can plan steps that can be taken to further their employment (McQuaid and Lindsay, 2005). Meanwhile, work orientation has strong relationship with job satisfaction which in turn affects their career development and employability skills (Nauta, 2009). Today, graduates require positive work orientation to prepare themselves to develop their career potential.

One of the weaknesses spotted by industries among Malaysian graduates who fail to get a job is low confidence level (Ranjit, 2009). Self-confidence can determine work patterns indirectly by helping someone to make responsible decisions. Those who have high self-confidence are able to accept their own weaknesses while being prepared to have different views of the organization. This ability develops individuals as well as enables them to prepare for the environment (Saputro and Suseno, 2010). Supported by Nasrudin (2004), that personality plays an important role in enabling new graduates to get a job. Therefore, the objective of this study is to identify the level of work orientation and self-confidence among new graduates who participated in Skim Latihan 1 Malaysia (SL1M). The researchers also intended to assess employability skills training programs, Skim Latihan 1 Malaysia (SL1M), in terms of capabilities and effectiveness in enhancing skills based on graduates' perceptions.

\section{Work Retention and Self-Confidence in Influencing Employability Skills}

Rapid technological change and the increasing demand for skilled labor have forced graduates to develop sufficient personal skills and be prepared to adapt to the changing workplace. In developing employability skills, one of the key factors is the work orientation. Individuals with positive thinking and skills are more likely to achieve more positive career outcomes such as work satisfaction and job suitability (Schien, 1990). Job suitability can be depicted by work orientation. Work orientation is the openness of employees to develop and adapt to changing job demands (Van Dam, 2004). In order to retain and enable employees to remain in an organization, workers need to be prepared to change the way they work, change the workplace, and be prepared to receive the training that their employer requires. Such changes are needed for employers to continue to ensure that their organization is ready to meet market demands. According to Schneider, Bief and Guzzo (1996), employers are willing to provide assistance to their employees by providing training to improve their work orientation so that employees are better prepared for organizational change.

Nauta et. al. (2009) conducted a study to look at employees' work orientation. The study shows that affordability has a positive relationship with work orientation while work orientation has a negative relationship with employee turnover. This finding has been supported by studies (Bezuijen, 2005; Parker, 2000; Van Dam, Oreg, da Schyns, 2008; Van Dam and Seijts, 2007) which also recommend that employability be closely related to work orientation. Nauta et al. (2009) also suggested that employers should concentrate on employability skills while ensuring they are always in line with current requirements. Neda and Jamaliah (2015) have examined the relationship between work orientation, leadership skills and self-efficacy among postgraduate students. The findings show that work orientation is strongly associated with leadership skills, which are one of the elements of employability skills that can help 
graduates improve their work quality and further their career enhancement. Local educational institutions need to apply work-oriented skills which are very important in helping students determine their career path.

Work orientation is also found to be at a high level among employees under 40 years old. They tend to possess higher levels of work orientation compared to older workers (Rendy, 2013). Hamsiah (2016) states that graduates with high job awareness and work orientation make it easier for them to secure a position in the job market. New graduates with high and positive work orientations tend to have a clear career pathway.

Krietner and Kinicki (2003) state that self-confidence is an individual's value to an organization's members to act within an organization. Self-confidence is closely related to one's willingness to enter the workforce. People who have high self-confidence are more likely to feel valued, important, and influential in their pursuit of work satisfaction within an organization. Afiatin and Martaniah (1998), graduates with high self-confidence, are certain in the decisions they make based on their skills and abilities. This enables one to do good work without the help of others. Individuals feel accepted by a group, allowing them to express their views more clearly and more responsibly to a group. Moreover, self-confidence is much needed for new graduates to understand themselves and determine what action to take in developing their potential for employment.

Self-confidence also plays a significant role in influencing employability skills. There is a significant relationship between self-confidence and employability skills. Students who are equipped with high self-confidence allow them to be more prepared to express themselves in the face of competition and to be more productive workers (Saputro \& Susemo, 2010). Training and self-esteem also can be motivation factors for students to be ready for the world of work (Martini \& Hartini, 2012). Supported by Patuhena (2008), Nazrifa (2012) and Yunita (2013), there is a positive relationship between self-confidence and work confidence as well as graduates' willingness to go to work.

Judge, Locke, Durham, and Kluger (1998) have proposed that self-confidence is one of the factors that affect an individual's level of work. People with high self-confidence perceive challenging task as an opportunity to be taken as advantage. Meanwhile, someone with low self-confidence may perceive it as an unwanted opportunity (Locke, McClear, and Knight, 1996). Korman (1970) also predicted that individuals with high self-confidence choose jobs that are consistent with their interests, leading to higher levels of job satisfaction.

\section{Methodology and Findings}

The design of this study is quantitative and descriptive by using a questionnaire instrument. Descriptive data were analyzed by using IBM SPSS Statistics software. The instrument is adapted from Mohd Hazwan Mohd Puad (2015) and Archer and Chetty (2013). The questionnaire comprises three sections; Part A is demographic information, Part B is graduate work orientation, Part C is graduate self-confidence. The questionnaire was validated by experts in the field of study from two different universities, Universiti Putra Malaysia and Universiti Pendidikan Sultan Idris. The population of the study consisted of new graduates who participated in the SL1M training program. They were enrolling to employability skills training program in Shah Alam, Selangor, Malaysia. The researchers selected the unemployed new graduates who participated in the SL1M program as the population based on the researcher's ability to obtain the information and data needed for the study. The training program companies were also willing to facilitate the researchers to conduct the study. A total of 108 respondents were selected from the SL1M program.

Pilot study was conducted before the actual data collection in order to examine whether the items in the questionnaire were compatible with the actual sample and to ensure the questionnaire contains clear meaning items and instructions. Pilot study on 30 graduates resulted alpha Cronbach 0.62 and it is acceptable to be used in research study. The researchers sent an application permission letter to conduct a study to companies who involved in the SL1M training program. Then, information on population was obtained from the companies. After obtaining the number of population, the minimum sample size of the study was calculated by using Cochran (1977) formula.

The findings of the study on demographic information are shown in Table 1 . The majority of the respondents in the study were female with $52.8 \%(\mathrm{n}=57)$ while male respondents were $47.2 \%(\mathrm{n}=51)$. The age of the respondents in the study ranged from under 23 to 29 years. According to the analysis, survey respondents aged 24 to 26 were the most likely to answer this questionnaire by $68.50 \%(\mathrm{n}=74)$ and followed by the survey respondents aged 27 to 29 at $23.1 \%(n=25)$. The respondents in the study were 23 years of age at $8.30 \%(n=9)$. The majority of respondents in the study received training at a company which involved in employability skills training programs under SL1M, Talent Sdn. Bhd. with a percentage of $68.50 \%(\mathrm{n}=74)$ and followed by Irsyad Sdn. Bhd. with a percentage of $31.50 \%(n=34)$. 
Table 1. Demographic information $(\mathrm{N}=108)$

\begin{tabular}{|c|c|c|c|}
\hline \multicolumn{2}{|c|}{ Demography } & Frequency & $\begin{array}{c}\text { Percentage } \\
\text { (\%) }\end{array}$ \\
\hline \multicolumn{2}{|c|}{ Gender } & & \\
\hline & Male & 51 & 47.20 \\
\hline & Female & 57 & 52.80 \\
\hline & Age & 9 & 8.3 \\
\hline & $24-26$ years old & 74 & 68.5 \\
\hline & $27-29$ years old & 25 & 23.1 \\
\hline & Training company & & \\
\hline & Irsyad & 34 & 31.50 \\
\hline & Talent Suites & 75 & 68.50 \\
\hline
\end{tabular}

\subsection{Work Orientation}

Table 2 shows the distribution of graduate work orientation levels. The analysis shows that work orientation construct is at a high level. The item "If the organization asks me to do other work, I am willing to change my activities and ways of work" shows the highest mean ( $\mathrm{M}=$ $2.81, \mathrm{SD}=0.40$ ) while the item "If the organization gives me the opportunity, I am willing to accept new work experience" shows the lowest mean compared to the other items $(\mathrm{M}=2.44, \mathrm{SD}=0.67)$.

\subsection{Self-Confidence}

Table 3 shows the distribution of self-confidence levels in response to the next objective. The analysis shows that the self-confidence construct is high. Based on the table, the item "Sometimes I think I am not good at something" showed the highest mean $(\mathrm{M}=4.28, \mathrm{SD}=0.86)$ and was followed by the item "I think that I have some good qualities" ( $\mathrm{M}=4.07, \mathrm{SD}=0.87)$, and "I feel useless at some point" $(\mathrm{M}=3.97, \mathrm{SD}=0.90)$. Furthermore, the item "I do not have much in myself to be proud of" showed the lowest mean compared to the other items $(\mathrm{M}=3.30, \mathrm{SD}=$ 1.17).

Table 2. Work orientation construct $(\mathrm{N}=108)$

\begin{tabular}{|c|c|c|}
\hline Item & Mean (M) & Standard Deviation (SD) \\
\hline $\begin{array}{l}\text { If my organization asks me to do another job, I am ready to change my activities and ways } \\
\text { of working }\end{array}$ & 2.81 & 0.40 \\
\hline $\begin{array}{l}\text { I feel it is important for me to develop myself more broadly to enable me to do the various } \\
\text { activities that the organization requires }\end{array}$ & 2.56 & 0.71 \\
\hline I feel it is important to get involved in activities that help develop my work & 2.56 & 0.66 \\
\hline If the organization changes, I had rather be in the existing section with my colleagues & 2.47 & 0.72 \\
\hline I'm ready to start work elsewhere & 2.71 & 0.45 \\
\hline If the organization gives me the opportunity, I am ready to receive new work experience & 2.44 & 0.66 \\
\hline If the organization is changing, $\mathrm{I}$ had rather be at my job now & 2.53 & 0.66 \\
\hline Total & 3.82 & 0.39 \\
\hline
\end{tabular}

Table 3. Self-confidence construct $(\mathrm{N}=108)$

\begin{tabular}{|c|c|c|}
\hline Item & Mean (M) & Standard Deviation (SD) \\
\hline Overall, I am satisfied with myself & 3.77 & 0.84 \\
\hline Sometimes I think I am not good at something & 4.28 & 0.86 \\
\hline I think that I have some good qualities & 4.07 & 0.87 \\
\hline I can do things like most people do & 3.38 & 1.02 \\
\hline I do not have much in myself to be proud of & 3.30 & 1.17 \\
\hline I feel useless at some point & 3.97 & 0.90 \\
\hline I think that I am a valuable person, at least at the same level as everyone else & 3.93 & 0.76 \\
\hline I hope to gain more self-respect & 3.69 & 0.99 \\
\hline I feel like I have succeeded in some things & 3.80 & 1.11 \\
\hline I take a positive attitude towards myself & 3.84 & 0.92 \\
\hline Total & 3.80 & 0.31 \\
\hline
\end{tabular}


Table 4. Graduates' perceptions on employability skills training programs (N=108)

\begin{tabular}{|c|c|c|}
\hline Item & Mean $(\mathrm{M})$ & Standard Deviation (SD) \\
\hline Employability skills training programs enhance graduates' ability to speak clearly & 1.62 & 0.49 \\
\hline Employability skills training programs improve graduates’ listening skills & 1.43 & 0.50 \\
\hline $\begin{array}{l}\text { Employability skills training programs enhance graduates' ability to communicate in } \\
\text { English }\end{array}$ & 1.53 & 0.50 \\
\hline Employability skills training programs enhance graduates' skills to work well in a group & 1.68 & 0.47 \\
\hline $\begin{array}{l}\text { Employability skills training programs enhance graduates' ability to understand their } \\
\text { function within a group }\end{array}$ & 1.39 & 0.49 \\
\hline $\begin{array}{l}\text { Employability skills training programs enhance graduates' skills to understand their role to } \\
\text { be a leader }\end{array}$ & 1.68 & 0.47 \\
\hline $\begin{array}{l}\text { Employability skills training programs enable graduates to learn the needs of lifelong } \\
\text { learning }\end{array}$ & 1.67 & 0.47 \\
\hline Employability skills training programs enable graduates to acquire lifelong learning skills & 1.42 & 0.50 \\
\hline $\begin{array}{l}\text { Employability skills training programs are capable of training graduates to practice lifelong } \\
\text { learning }\end{array}$ & 1.56 & 0.50 \\
\hline $\begin{array}{l}\text { Employability skills training programs are able to train graduates to understand human } \\
\text { needs as well as social issues }\end{array}$ & 1.74 & 0.44 \\
\hline Employability skills training programs enhance the degree of professionalism of graduates & 1.66 & 0.48 \\
\hline $\begin{array}{l}\text { Employability skills training programs are able to train graduates to take responsibility for } \\
\text { their actions }\end{array}$ & 1.74 & 0.44 \\
\hline $\begin{array}{l}\text { Employability skills training programs enable graduates to identify problems in the } \\
\text { workplace }\end{array}$ & 1.63 & 0.49 \\
\hline $\begin{array}{l}\text { Employability skills training programs are capable to train graduates to use experience to } \\
\text { solve problems }\end{array}$ & 1.31 & 0.46 \\
\hline $\begin{array}{l}\text { Employability skills training programs are able to train graduates to apply the knowledge to } \\
\text { solve problems }\end{array}$ & 1.46 & 0.50 \\
\hline Total & 1.57 & 0.23 \\
\hline
\end{tabular}

\subsection{Self-Confidence}

Table 4 shows the role of employability skills training programs, Skim Latihan 1 Malaysia (SL1M), in terms of capabilities and effectiveness in enhancing skills based on graduates' perceptions.

The analysis found that the mean values for the items "Employability skills training programs are able to train graduates to be responsible for their actions" and "Employability skills training programs are able to train graduates to understand human needs and social issues" were highest $(M=1.74, S D=0.44)$ and followed by the items "Employability skills training programs enhance the skills of graduates to work well within a group" and "Employability skills training programs enhance graduates' skills to understand their role to be a leader" $(\mathrm{M}=1.68, \mathrm{SD}=0.47)$. The item "Employability skills training programs are able to train graduates to use experience to solve problems" is the item with the lowest mean value $(\mathrm{M}=1.31, \mathrm{SD}=0.46)$.

It can be concluded that the self-confidence and work orientation factors are at a high level. Graduates are prepared to change the way they work when directed by their organization. Also, this indicates that new graduates possess a positive work orientation. Moreover, trainees in the SL1M training program are confident and possess the right attitude to be hired in the labor market. Meanwhile, most of the mean items in graduates' perceptions on employability skills training programs are at low level.

\section{Discussion and Conclusions}

Through the results of work orientation and self-confidence level, new graduates are moderately prepared to change the way they work when directed by their organization. This indicates that new graduates produced have high levels of work orientation. Training centers, especially high schools and SL1M programs are seen to have developed a high degree of positive work orientation among new job seekers. Respondents from both companies of employability skills training programs appeared to be receiving additional training in order to be more self-sufficient and willing to accept more tasks. Supported by Van Dam (2004), employees are likely to improve their work orientation if given the opportunity to be in a new situation. Rendy (2013) stated that young workers generally under 40 years old tend to possess a higher level of work orientation than those who are older. However, most respondents indicated that they were more comfortable working with existing colleagues. Respondents are more interested in the work environment with existing colleagues than in the new workplace. Supported by Hamsiah (2016), graduates possess work orientation that helps them to determine their own career path.

In addition, the findings also depict that graduates possess a high degree of self-confidence. They believe that they have a good quality to be themselves and things can be proud of. However, respondents still acknowledged that they sometimes find themselves weak to do 
something especially something new in terms of job tasks, assignments. Saputro and Susemo (2010) stated that graduates always possess confidence to work and that confidence is related to their employability skills.

Graduates who are seeking a job position have a high awareness of the issues of employability skills and competition that exist in the job market. They are aware of the role of employability skills training programs such as SL1M program in enhancing skills and reducing unemployment among university and college graduates. However, the results show their perception at a low level with a mean value of 2.442 and a standard deviation of 0.229 . They perceived that the SL1M training program was not effective in fulfilling its role in preparing unemployed graduates before entering the workforce. This finding is aligned with previous studies by Mohd Hazwan Mohd Puad (2018) that shows the training centers are unable to fulfill their role to effectively train graduates with much needed employability skills by employers.

\section{Recommendation}

For the recommendation, further research should be conducted on other factors or constructs such as motivation, interest in identifying the strongest variables that influence graduates' employability skills. Moreover, future researchers could also conduct interviews with the respondents involved the training programs in order to obtain the whole picture in conducting the qualitative study. To be balanced in terms of perceptions, future researchers should also add inputs by from employers and training center providers as survey respondents.

\section{REFERENCES}

[1] Ministry of Education. (2019). Laporan Pengesanan Graduan 2017, Putrajaya.

[2] Muhammad Hazrul Ismail. (2012). Kajian Mengenai Kebolehpasaran Siswazah di Malaysia: Tinjauan dari Perspektif Majikan, Prosiding PERKEM VII, jilid 2 (2012) $906-913$.

[3] A. Abiewskiro,. Z. Moplskiiera. The Problemo of Grammar Choice For Verification, TCSET of the International Conference, House of Lviv Polytechnic National University, 19-23, 2008.

[4] Department of Statistics Malaysia. (2019). Report of Labor Workforce. Kuala Lumpur.

[5] Chang, M. (2004). Why Some Graduate are More Marketable than Others: Employer's Perspective. Kertas Kerja Dibentangkan dalam Workshop on Enhancing Graduate Employability in a Globalised Economy. Unit Perancang Ekonomi Malaysia.

[6] Nurita, Shaharudin \& Ainon (2004). A survey of students' employability skills: A Case of UNITAR.

[7] Mohd Hazwan Mohd Puad. (2018). Obstacles to Employability Skills Training Programs in Malaysia from the Perspectives of Employers', Educators' and Graduates.
International Journal of Academic Research in Business \& Social Sciences, 8(10), 952-972.

[8] Mohd Hazwan Mohd Puad. (2015). The Role of Employability Skills Training Programs in the Workforce of Malaysia (Doctoral degree thesis). Retrieved from ProQuest Library.

[9] Nauta, A., van Viane, A., van der Heijden, B., van Dam, K. \& Willemsen, M. (2010). Understanding the factors that promote employability orientation: The impact of employability culture, career satisfaction, and role breadth self - efficacy, Jounal Of Occupation And Organization Psychology. Volume82, Issue2

[10] Ranjit Sing (2008) Malaysian Graduates Employability Skill, UniTAR E-Journal, 4(1), 15-45

[11] Niko Dimas Saputro \& Miftahun Ni'mah Suseno (2010) Hubungan Antara Kepercayaan Diri dan Emplyability Pada Mahasiswa, Universitas Islam Indonesia.

[12] Nasrudin Mohamed (2004) Graduates Unemployment, Perspective and Brief Journal Analysis, Journal of Admistrative Sciece.

[13] Rendy Karuniya (2013) Pengaruh Orentasi KerjaTerhadap Kinekerja Guru SMA Xaverius 1 Palembang. Journal Kewangan dan Bisnes.

[14] Hamsiah Djafar (2016). Faktor Yang Mempengaruhi Tingginya Tingkat Minat Mahasiswa Terhadap Jurusan MAnajemen Pendidikan Di UIN Alaudin Makasar. jurnal Manajemen Pendidikan Volume V, N0 2.

[15] Krietner R. Dan A. Kinicki. (2003). Perilaku Organisasi, Edisi Pertama, Jakarta:Selemba Empat.

[16] Afiatin, T. \& Martaniah, S.M. (1998). Peningkatan Kepercayaan Diri Remaja Melalui Konseling Kelompok. Jurnal Psikologika, No. 6, Tahun III, 1998.

[17] Martini Mach D. \& Hartini N. (2012). Hubungan Antara Penerimaan Diri Dengan Kecemasan Menghadapi Dunia Kerja Pada Tunadaksa Di UPT Rehabilitasi Sosial Cacat Tubuh Pasuruan, Jurnal Psikologi Klinis dan Kesehatan Mental, Vol. 1 No. 02.

[18] Putehena Poka (2008). Pengaruh kepuasan Kerja Terhadap Kinekerja dengan Self-esteem Dan Self Efficiency Sebagai Variable Interventing, Jurnal Bisnes Dan Akutansi Vol 10 No 1 April 2008, Universiti Pattimura.

[19] Nazrifa, I. T. (2012) Kebolehpasaran graduan bermasalah pendengaran bidang hospitaliti dalam industri hospitaliti di Malaysia. Masters thesis, Universiti Tun Hussein Onn Malaysia.

[20] Judge, T. A., Locke, E. A., Durham, C. C., \& Kluger, A. N. (1998). Dispositional effects on job and life satisfaction: The role of core evaluations. Journal of Applied Psychology, $83,17-34$.

[21] Locke, E. A., McClear, K., \& Knight, D. (1996). Self-esteem and work. International Review of Industrial/Organizational Psychology, 11, 1-32

[22] Korman, A. K. (1970). Toward an hypothesis of work behavior. Journal of Applied Psychology, 54, 31-41.

[23] Archer dan Chetty (2013), Graduate Employability: Conceptualisation and findings from the University of South Africa, Progressio 35 (1) 2013 pp134-165.

[24] Cochran, W. G. (1977). Sampling Techniques (3rd ed). New York: John wiley \& Sons. 